\author{
Ю.І. Бойко, к.т.н., доц. \\ О.А. Литвиненко, Д.т.н., проф. \\ Національний університет харчових технологій
}

В.А. Яновський, доц.

Державний університет «Житомирська політехніка»

\title{
Оцінка впливу режимів різання на вібрацію розточувального різця і точність оброблюваних отворів на верстатах з ЧПК
}

\begin{abstract}
На точність механічної обробки отворів суттєво впливають такі фактори, як вібрачіі, щчо неминуче виникають у процесі виготовлення деталей у технологічній оброблювальній системі (ТОC). Серед них вібрачія різального інструменту є найбільш негативним явищем, оскільки вона впливає на точність і шорсткість оброблених поверхонь, працездатність верстата та термін служби иьього інструменту.

Консольне закріплення різального інструменту під час розточування отворів зменшує жорсткість ТОС, що призводить до зниження їх точності. На сьогодні відсутні системні дослідження впливу вібраційної жорсткості консольного закріплення інструментів на точність одержаних отворів. Тому дослідження впливу вібрацій розточувального різия на точність обробки отворів на верстатах з числовим програмним керуванням (ЧПК) набуває важливого практичного значення.
\end{abstract}

Під час обробки деталей на сучасних металорізальних верстатах з ЧПК їх прачездатність можна визначити за показниками потенџіометра, що дозволяє аналізувати ефективність процесу різання, його стабільність, амплітуду та величину вібрацій інструмента.

У статті на прикладі розроблення технологічного маршруту механічної обробки деталі штифта плаваючого, що призначений для забезпечення центрування напрямних у корпусі пресформи, з використанням CAD-CAM системи «Inventor 3D» та програми "Siemens NX»проаналізовано вплив вібрачій різального інструменту, щуо виникають у ТОС в процесі обробки, на точність розточування отворів.

Завдання вирішувалося під час розточування точних отворів діаметром $30 H 7$ у заготовках із загартованої сталі $40 X$ за допомогою розточувального антивібраџійного різия фірми «Sandvik-A20S-STFCR 11-RB1 CoroTurn 107», оснащеного змінною твердосплавною пластиною TCMT090204-UM. Дослідження проводили на сучасному токарно-фрезерному обробному центрі з ЧПК моделі HAAS DS-30Y.

Теоретично показано, щзо зменшення вібрачії розточувального різия під час розточування точного отвору досягається за таких режимів різання: глибина $t=0,4$ мм, подача s $=0,1$ мм/об та частота обертання шпинделя $n$, яка в інтервалі часу «розгон-гальмування» 2 секунди змінюється, тобто збільшується від $n=1800$ об/хв до $n=2000$ об/хв і навпаки, що дозволяє отримати отвір $\varnothing 30 Н 7$ з допуском изліндричності до 0,02 мм на довжині 100 мм.

Ключові слова: технологічна оброблювальна система; вібрачї; різальний інструмент, режими різання; САD-САМ системи; верстат з ЧПК; якість; точність.

Постановка проблеми. Процес обробки різанням $\epsilon$ універсальним методом формоутворення поверхонь деталей, що дозволяє обробляти деталі з поверхнями різних форм і розмірів. Цей процес характеризується задовільною питомою енергоємністю і високою продуктивністю. На сьогодні обробка різанням є основним найбільш поширеним у машинобудуванні процесом виготовлення деталей.

Найбільш складним і відповідальним завданням забезпечення лезової обробки металів є вибір та призначення параметрів режимів різання. Існуючі рекомендації щодо вибору режимів різання дають орієнтовні значення швидкості різання $(V)$ та подачі $(S)$, які доводиться постійно уточнювати на практиці для конкретних технічних умов обробки. Тому вибір раціональних параметрів швидкості різання $(V)$ (частоти обертання заготовки) і подачі $(S)$ з урахуванням їх впливу на стружкоутворення, види стружки, витрату мастильно-охолоджувальних рідин (МОР) впливає на якісні показники механічної обробки деталей $[1,2]$.

Крім того, одним зі шляхів забезпечення підвищення ефективності процесу механічної обробки є раціональне використання сучасних засобів виготовлення деталей на базі комп'ютерних CAD-CAM технологій та верстатів з числовим програмним керуванням [3, 4].

В той же час на якість механічної обробки деталей суттєво впливають такі фактори як вібрації, що неминуче виникають у процесі виготовлення деталей. Цей напрям потребує науково-практичних досліджень. 
Під час проєктування операції розточування точних отворів важливим $є$ не тільки вибір параметрів режимів різання. Консольне закріплення різального інструменту під час розточування отворів зменшує жорсткість технологічної оброблювальної системи, що призводить до зниження точності оброблюваних отворів. На сьогодні відсутні системні дослідження впливу вібраційної жорсткості консольного закріплення інструментів на точність одержаних отворів. Близько $70 \%$ відмов технологічної оброблювальної системи пов'язані з підвищеним рівнем вібрації.

Під час обробки деталей на сучасних металорізальних верстатах з ЧПК їх працездатність можна визначити за показниками потенціометра, який дозволяє аналізувати ефективність процесу різання, його стабільність, амплітуду і частоту коливань інструмента. Тому завдання підвищення вібростійкості технологічної оброблювальної системи набуває важливого практичного значення.

Аналіз останніх досліджень. Сучасне машинобудування ставить жорсткі умови до якості продукції. Вона забезпечується використанням у виробничих процесах сучасних CAD-CAM технологій i оброблювальних центрів з ЧПК. Це гарантує високий рівень автоматизації, продуктивність, гнучкість при переналагодженні й дозволяє оптимізувати як технологічний процес, так і його економічні показники. За таких умов забезпечується точність і високі експлуатаційні показники виробів [3].

Вібростійкість технологічної системи значною мірою залежить від автоколивань. Вони впливають на продуктивність і надійність верстата, якість обробленої поверхні та залежать від параметрів руху коливальної системи за наявності змінної сили. Під час розточування отворів можливі вібрації станини, різцетримача, супорта, оправки різця, заготовки, а також крутильні коливання заготовки і шпинделя, вібрації передньої бабки. Серед них вібрація різального інструменту є найбільш негативним явищем, оскільки впливає на інтенсивність зносу інструмента, точність розмірів оброблюваної заготовки, працездатність верстата, термін служби різального інструменту та якість обробленої поверхні. Особливо ці показники залежать від інтенсивності автоколивань. Аналіз причин виникнення автоколивань дозволяє істотно знизити їх вплив на процеси різання $[5,6]$.

Метою статті $\epsilon$ висвітлення результатів досліджень авторів щодо визначення впливу параметрів режимів різання та конструкції розточувального різця на вібрації в процесі механічної обробки. Завдання вирішувалося під час розточування точних отворів діаметром $30 \mathrm{H7}$ у деталі «штифт плаваючий», виготовленої із загартованої сталі $40 \mathrm{X}$ за допомогою сучасного антивібраційного розточувального різця. Дослідження виконували на токарно-фрезерному обробному центрі з ЧПК моделі HAAS DS-30Y iз застосуванням програмного забезпечення в системі «Siemens NX».

Викладення основного матеріалу. Під час вибору раціональних режимів різання для операції глибокого розточування отворів необхідно забезпечити: стабільне подрібнення та надійне видалення стружки потоком МОР по всій довжині робочого ходу; економічно обгрунтовану стійкість різального інструмента, тобто час його роботи до настання гранично допустимого зносу леза; допустимий рівень коливань розточувального різця і заготовки (відсутність вібрації); отримання заданої точності та якості поверхні оброблюваного отвору; функціонування процесу та підвищення його ефективності порівняно із застосовуваною технологією.

Для визначення параметрів режимів різання під час розточування отворів було використано імітаційне моделювання і проведено комп'ютерний аналіз у системі «Inventor 3D». Моделювання та комп'ютерний аналіз містить визначення величини переміщення робочої кромки різальної пластини різця за статичного навантаження з урахуванням температурного впливу. За основу моделі було взято розточувальний токарний різець фірми «Sandvik-A20S-STFCR 11-RB1 CoroTurn 107» (рис. 1).

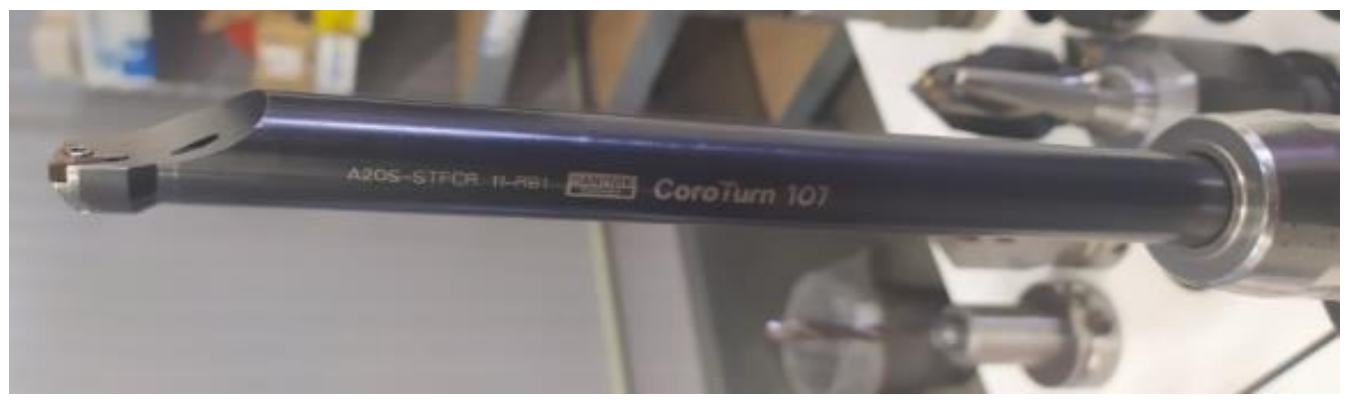

Puc. 1. Розточувальний різецьь фірми «Sandvik-A20S-STFCR 11-RB1 CoroTurn 107»

Автори застосували для моделювання програмне CAD-CAM-CAE-системне забезпечення «Siemens NX» (раніше «Unigraphics) компанії «Siemens PLM Software». Система використовує ядро геометричного моделювання Parasolid. NX підтримує широкий спектр операційних систем, в тому числі Windows, Mac OS X, UNIX / Linux. 
До складу конструкторських програм NX входять підпрограми для проєктування деталей та агрегатів, створення моделей конструктивних елементів. Засоби промислового дизайну забезпечують проєктування поверхонь різноманітної геометричної форми, розв'язання задач зворотної розробки, інтеграції 3 конструкторськими CAD-системами, системами інженерного аналізу - CAE та технологічними системами CAM. До складу систем входять: «Freeform Shape» - пакет автоматизованого промислового дизайну; «Dynamic \& Photorealistic Rendering»- пакет створення візуальних зображень виробів.

На основі отриманих даних у системі «Siemens NX» формується 3D-поверхнева твердотільна модель деталі. «Siemens NX» дозволяє забезпечити моделювання деталей, провести аналіз перетинів i розрахунок маси та підготувати 2D- або 3D-креслення. Засоби проєктування механічних систем дають змогу поєднувати в проєкті механічні елементи та інформацію про логічні підключення. У складі «Siemens NX» є технологічний CAM-модуль підготовки керуючих програм для верстатів з ЧПК, що підтримує різні види обробки: токарну, фрезерну на 3-5-осьових верстатах з ЧПК, токарно-фрезерну, електроерозійну обробку. Система NX CAM підтримує прогресивні види обробки і технологічне обладнання: високошвидкісне фрезерування, зокрема обробку на токарно-фрезерних багатофункціональних верстатах [7].

Моделювання здійснювали для розроблення технологічного маршруту та керуючої програми виготовлення деталі «штифт плаваючий» (рис. 2), що призначений для центрування напрямних у корпусі прес-форми.

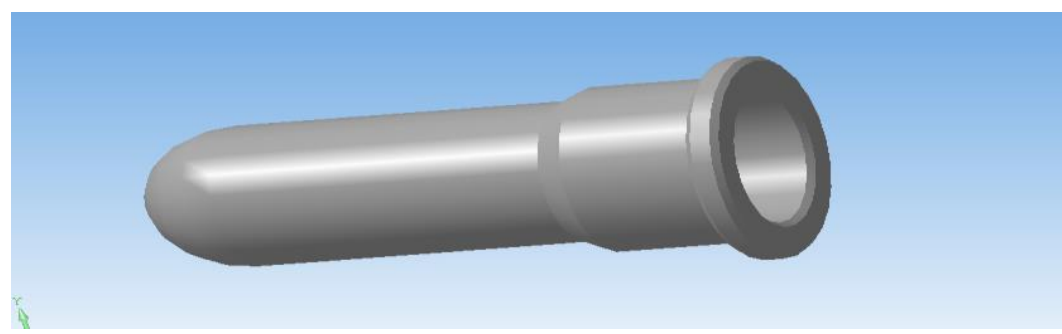

Рис. 2. Зовнішній вигляд штифта (3D-модель у програмі «Siemens NX»)

Моделювання технологічного процесу обробки деталі у середовищі «Siemens NX» здійснювали в такій послідовності. На першому етапі моделювання в середовище програми завантажували готовий

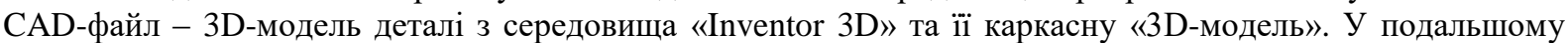
задавали параметри розміщення деталі відносно системи координат, вибрали заготовку у вигляді прутка діаметром 35 мм.
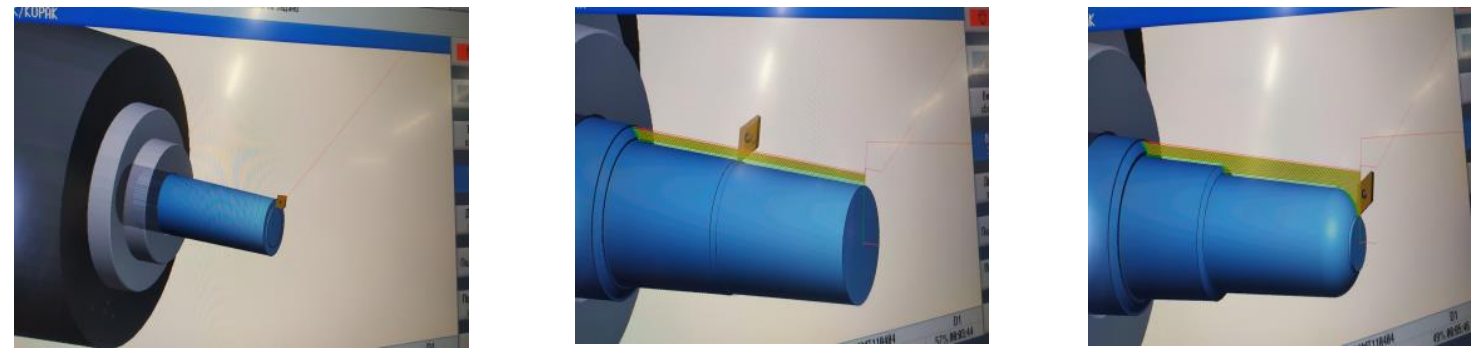

Pис. 3. Поетапне завантаження і візуалізація обробки в програмі «Siemens NX»

На рисунку 3 показано заготовку деталі і початок відліку осей координат. Початкові точки для відліку обрано по координаті $(Z)$ - від торця деталі, а по координаті $(X)$ - від зовнішнього діаметра заготовки.

На наступному етапі моделювання в програмному середовищі був обраний інструмент для оброблення деталі, задано початкову точку, розміщену на певній відстані від заготовки для уникнення зіткнення 3 нею (рис. 4). Після створення зазначених елементів було безпосередньо обрано траєкторію руху різального інструмента 3 призначенням режимів різання, підведенням і відведенням інструмента. Після задання параметрів, необхідних для процесу обробки, програма розрахувала траєкторії руху інструмента. В подальшому був проведений аналіз траєкторії руху інструмента, а також проаналізована можливість перенавантажень інструмента та виходу його з ладу. 
Після цього у вікні перегляду візуалізації в мультимедійній формі відображено процес оброблення на верстаті, враховуючи операції підведення і відведення інструмента, а також контролю унеможливлення зіткнень інструмента $з$ деталлю та його врізання в деталь.

Механічну обробку деталі здійснювали на токарно-фрезерному обробному центрі з ЧПК моделі HAAS DS-30Y. Для охолодження використовували мастильно-охолоджувальну емульсію марки «Blasocut 4000» виробництва «Blaser Swisslube AG». «Blasocut 4000» - це водозмішувана емульсія на основі мінеральної оливи, яка не містить хлорних з'єднань. Вона застосовується для обробки різноманітних конструкційних матеріалів (чавун, сталь, алюмінієві сплави).

Після обробки траєкторії руху в середовищі програми «Siemens NX» iï завантажували в постпроцесор, що призначений для верстата HAAS DS-30Y, і виконували процес обробки деталі (рис. 6).

У процесі механічної обробки цієї деталі основною технологічною проблемою, що виникла, було розточування точного отвору діаметром $30 \mathrm{H} 7$, витримуючи при цьому відхилення від циліндричності отвору 0,02 мм на довжині 100 мм.

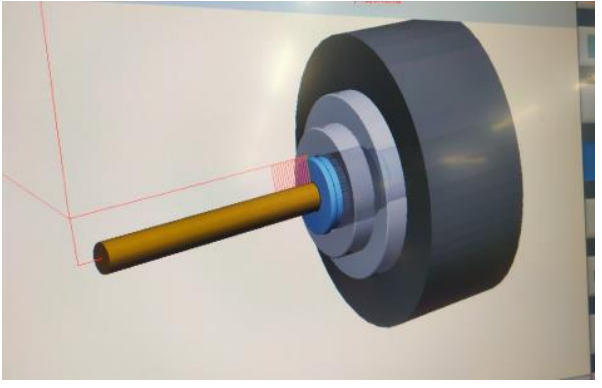

Рис. 4. Траєкторія руху інструмента під час обробки

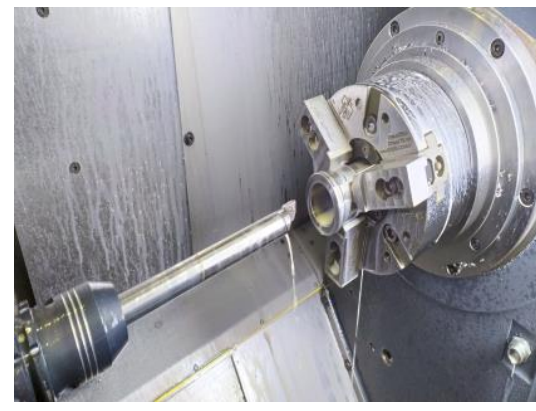

Puс. 5. Розточування отвору на верстаті HAAS DS- $30 Y$ антивібраційним розточувальним різием

Залежно від призначення отвори характеризуються за точністю, шорсткістю та співвідношенням діаметра і довжини. Сьогодні виробники різального інструменту пропонують свої параметри режимів різання для обробки всіх типів отворів. Однак для ефективного використання новітніх різальних інструментів у виробництві недостатньо простого використання рекомендацій виробників та постачальників, що наведені в каталогах.

Однією з основних причин, яка не дозволяє реалізувати можливості різального інструменту, є вібрації. Вони обмежують можливість підвищення режимів різання і продуктивності праці. Коливання інструмента відносно заготовки викликають періодичну зміну товщини зрізаного шару і сил різання, величину та характер навантажень на верстат, що збільшуються в кілька разів порівняно 3 усталеним режимом різанням. Навіть слабкі вібрації технологічної системи перешкоджають досягненню високого класу шорсткості і отримання отворів із заданою точністю. При цьому стійкість інструмента, особливо твердосплавного і мінералокерамічного, значно знижується. Знакозмінні динамічні навантаження зменшують ресурс інструмента та верстата. Під час виникнення вібрацій доводиться зменшувати оберти та глибину різання, але при цьому збільшувати подачу до величини, яка не має перевищувати радіус заокруглення ріжучої кромки. Крім зниження режимів різання, значно погіршуються економічні показники процесу різання за рахунок збільшення тривалості технологічного процесу [8].

Вібрації технологічної системи можуть виникати у вертикальній і горизонтальній площинах, паралельно або перпендикулярно напрямку подачі; призводять до відносного переміщення заготовки та різця, зміни параметрів режимів різання (тобто швидкості різання, глибини різання і подачі), що $\epsilon$ основною причиною виникнення змінної сили різання. Висока жорсткість і низька маса системи забезпечують умови для зменшення вібрації. Вібрацію також можна зменшити за рахунок збільшення міцності та твердості оброблюваного матеріалу.

При зменшенні головного і допоміжного кутів у плані різця ( $\varphi$ i $\left.\varphi_{1}\right)$ збільшується радіальна сила різання $(P y)$, за рахунок чого зростає інтенсивність вібрації. Чим більше радіус заокруглення при вершині різця в плані, тим більша амплітуда коливань.

Стандартною процедурою, прийнятою для зменшення вібрації під час обробки різанням, $є$ раціональний вибір режимів різання. Методи, які використовуються для зниження вібрації, засновані на імітаційному моделюванні та підтверджуються експериментальними дослідженнями, що дозволяють отримати оптимальні умови різання [8-10]. 
Автори проводили дослідження залежності розмірної точності та якості поверхні отвору від вібрацій під час різання і визначення оптимальних режимів різання. Режими різання для розточування отвору призначали за рекомендаціями виробника інструмента.

Під час розточування отвору штифта діаметром $30 H 7$ у виробничих умовах з використанням режимів різання, рекомендованих виробником для розточувального різця фірми «Sandvik-A20S-STFCR 11-RB1 GroTurn 107» та оснащеного змінною твердосплавною пластиною TCMT090204-UM, не вдалося досягти заданих технічних вимог до його точності, а саме відхилення від циліндричності 0,02 мм на довжині 100 мм. Особливо це проявлялося під час проходження різцем відстані, більшої за три діаметри оброблювального отвору, коли виникали підвищені вібрації, які відображав потенціометр верстата HAAS DS-30Y (рис 6). Це засвідчувало погіршення шорсткості поверхні оброблюваного отвору та його відхилення від циліндричності. Після розточування отримали отвір 3 квалітетом точності по IT8. Контроль здійснювався нутроміром Мarh з точністю вимірювання - 0,005 мм. Результати проведених експериментальних досліджень наведені в таблиці 1.

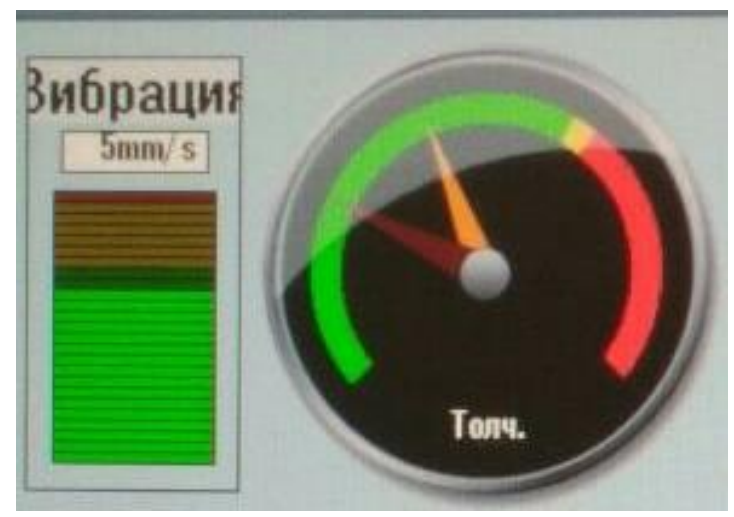

Puc. 6. Потениіометр верстата HAAS DS-30Y для визначення величини вібрації під час розточування отвору

3 аналізу величини вібрацій (табл. 1) зрозуміло, що найбільш стабільне різання забезпечується за таких умов: частота обертів шпинделя $n=1900$ об/хв, глибина різання $t=0,4$ мм, подача $s=0,1$ мм/об, але при цьому не забезпечується задана точність розточеного отвору.

При подальшому вирішенні цієї проблеми та на основі проведеного аналізу літературних джерел $[5,6,9]$ було запропоновано, що вібрації під час оброблювання отворів можна зменшувати шляхом зміни швидкості обертання деталі у певному проміжку часу.

Режими різання та їх вплив на відхилення від цฺиліндричності

Таблиия 1

\begin{tabular}{|c|c|c|c|c|c|}
\hline $\begin{array}{c}\text { № } \\
\text { досліду }\end{array}$ & $\begin{array}{c}\text { Оберти } \\
\text { шпинделя } \\
n, \text { об/хв }\end{array}$ & $\begin{array}{c}\text { Глибина } \\
\text { різання } t, \text { мм } \\
\text { на сторону }\end{array}$ & $\begin{array}{c}\text { Подача } s, \\
\text { мм/об }\end{array}$ & $\begin{array}{c}\text { Значення } \\
\text { потенціометра, } \\
\text { мкм/с }\end{array}$ & $\begin{array}{c}\text { Відхилення від } \\
\text { циліндричності, } \\
\text { мм }\end{array}$ \\
\hline 1 & 1800 & 0,4 & 0,1 & 3,6 & 0,04 \\
\hline 2 & 1900 & 0,4 & 0,1 & 3,0 & 0,03 \\
\hline 3 & 2000 & 0,4 & 0,1 & 3,5 & 0,04 \\
\hline 4 & 1900 & 0,3 & 0,1 & 3,8 & 0,04 \\
\hline 5 & 1900 & 0,4 & 0,1 & 4,0 & 0,04 \\
\hline 6 & 1900 & 0,5 & 0,1 & 4,8 & 0,05 \\
\hline 7 & 1800 & 0,4 & 0,05 & 6,0 & 0,05 \\
\hline 8 & 1900 & 0,4 & 0,1 & 7,2 & 0,06 \\
\hline 9 & 2000 & 0,4 & 0,12 & 8,0 & 0,07 \\
\hline
\end{tabular}

3 цією метою під час обробки деталі на токарно-фрезерному центрі з ЧПК моделі HAAS DS-30Y було використано цикл «S_ALTERNIEREN» (рис. 7) в середовищі керуючої програми, що дозволяє змінювати частоту обертів шпинделя у заданому діапазоні за визначений інтервал часу.

Для досягнення більшої точності отвору до IT7 автори дослідили вплив зміни швидкості обертання заготовки від 1800 до 2000 об/хв в інтервалі часу $T$ від 1 до 7 с на параметри вібрації технічної системи. 


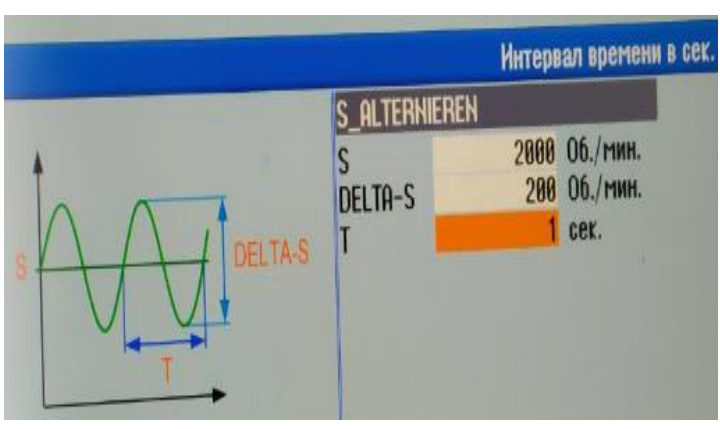

a)

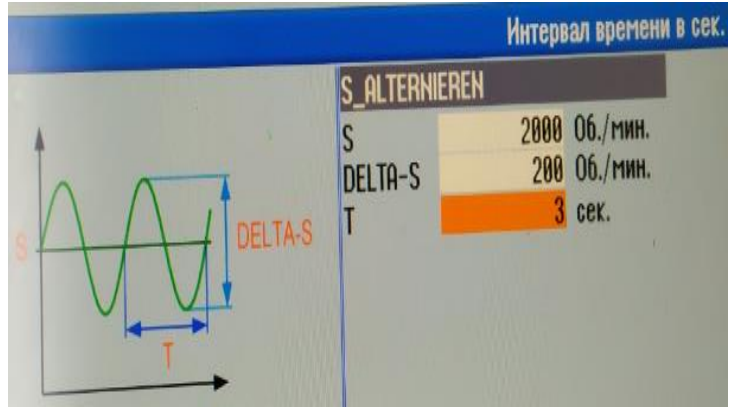

б)

PUс. 7. Візуалізація завантаження цииклу «S_ALTERNIEREN» керуючої програми залежно від інтервалу часу «T»: a) $-1 c ; \sigma)-2 c$

На основі таких отриманих залежностей показників потенціометра верстата та інтервалу часу побудована графічна залежність (рис. 8).

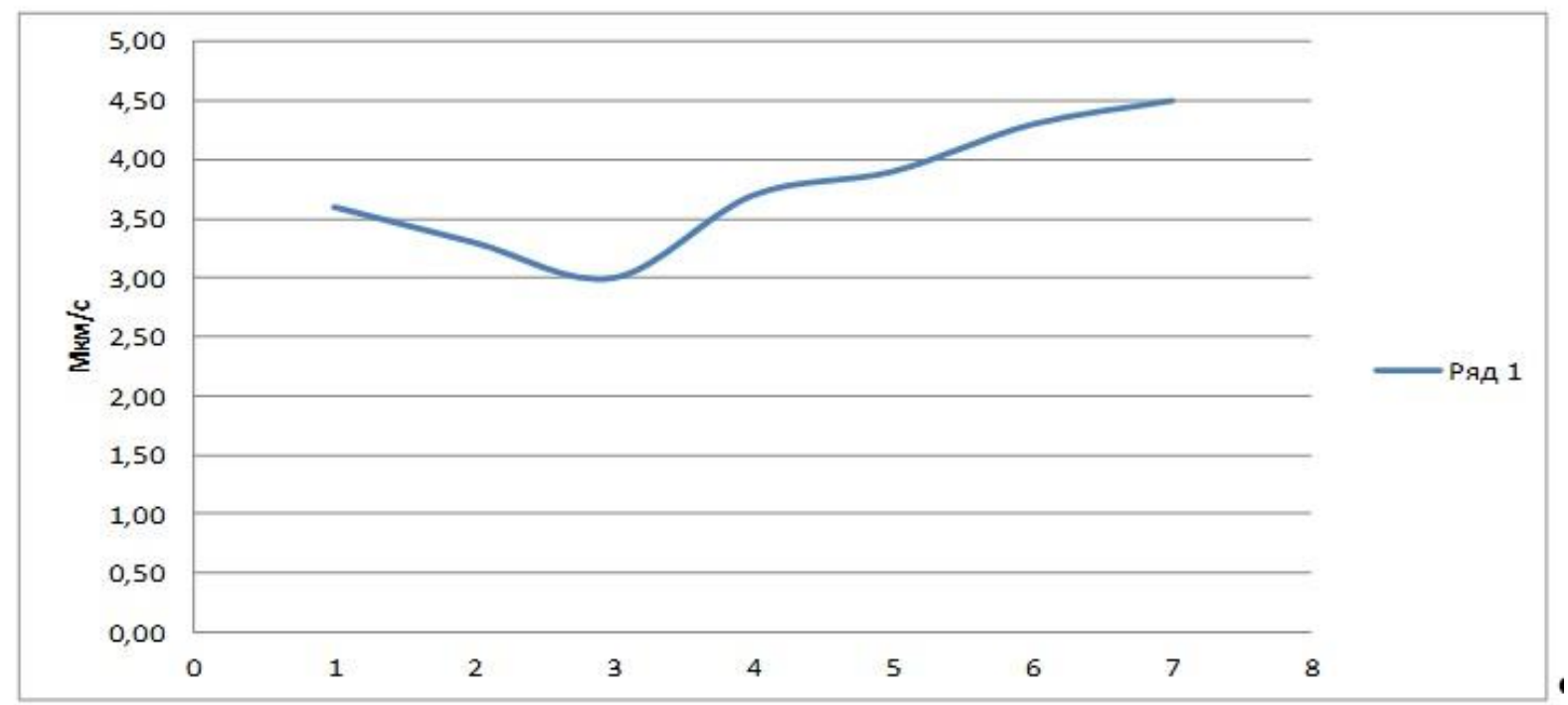

Рис. 8. Залежність вібраџії інструмента від інтервалу часу зі зміною частоти обертання шиннделя

Аналіз одержаних результатів свідчить, що найбільш стабільне різання забезпечується за таких умов: оберти шпинделя $n=1800-2000$ об/хв, глибина різання $t=0,4$ мм, подача $s=0,1 \mathrm{Mm} /$ об за інтервал часу «розгон-гальмування» 2 с у цьому інтервалі $n$. Вимірювання нутроміром Мarh обробленої поверхні отвору показало, що точність отриманого розміру обробленої поверхні отвору знаходиться в межах допуску квалітету IT7.

Висновки. Досліджено вплив режимів різання на обробку точних отворів на токарно-фрезерному обробному центрі HAAS DS-30Y з використанням антивібраційного розточувального різця фірми «Sandvik-A20S-STFCR 11-RB1 CoroTurn 107», оснащеного змінною твердосплавною пластиною TCMT090204-UM.

Показано, що зменшення вібрації розточувального різця під час розточування точного отвору досягається за таких режимів різання: глибина $t=0,4$ мм, подача $s=0,1 \mathrm{mм} /$ об та частота обертання шпинделя $n$, яка в інтервалі часу «розгон-гальмування» 2 с змінюється, тобто збільшуються від $n=1800$ до $n=2000$ об/хв і навпаки, що дозволяє отримати отвір $\varnothing 30 \mathrm{H} 7$ допуском циліндричності до 0,02 мм на довжині 100 мм.

\section{Список використаної літератури:}

1. Технологія машинобудування : підручник / П.П. Мельничук, А.І. Боровик, П.А. Лінчевський, Ю.В. Петраков. - Житомир : ЖДТУ, 2005. - 835 с.

2. Михайлов В.M. Технологічні основи машинобудування : навч. посібник у 2 ч. Ч. 1. / В.M. Михайлов, I.В. Бабкіна, Б.В. Ляменко. - Харків : ХДУХТ, 2009. - 202 с. 
3. Ловыгин А.А. Современный станок с ЧПУ и САD/САМ-система / А.А. Ловыгин, Л.В. Твердовский. - М. : ДМК Пресс, 2012. - 280 с.

4. Литвиненко O.A. САD/CAM технології проектування та виготовлення деталей на верстатах з ЧПК / О.А. Литвиненко, Ю.І. Бойко, В.А. Яновський // Технічна інженерія. - 2020 р. - № 1 (85). - С. 15-22.

5. Тюкина Н.В. Особенности растачивания глубоких отверстий / Н.В. Тюкина // Известия ТулГУ. Технические науки. - 2014. - Вып. 11. - Ч. 1. - С. 189-103.

6. Roukema J.C. Generalized modeling of drilling vibrations: Part II: Chatter stability in frequency domain / J.C. Roukema, Y.Altintas // Intenational Jornal of Machine Tools \& Manufacture. - 2007. - № 47. - P. 1474-1485.

7. Siemens NX [Електронний pecypc]. https://www.plm.automation.siemens.com/global/ru/products/nx/.

8. Хорошайло B.B. Повышение эффективности растачивания отверстий на токарных станках путем создания виброустойчивой инструментальной системы : автореф. дисс. ... канд. техн. наук : $05.03 .01 /$ B.B. Хорошайло ; Донбасская государственная машиностроительная академия. - Краматорск, 2016.

9. Технологія автоматизованого виробництва : підручник / О.О. Жолобов, В.А. Кирилович, П.П. Мельничук, B.A. Яновський. - Житомир : ЖДТУ, 2010. - 1014 с.

10. Boucher Michelle Стратегия основных поставщиков CAD- и CAE-систем в 2014 году и дальше / Michelle Boucher [Електронний ресурс]. - Режим доступу : http://www.cadcamcae.lv/N89/22-30.pdf.

\section{References:}

1. Mel'nychuk, P.P., Borovyk, A.I., Linchevs'kyj, P.A. and Petrakov, Ju.V. (2005), Tehnologija mashynobuduvannja, pidruchnyk, ZhDTU, Zhytomyr, 835 p.

2. Myhajlov, V.M., Babkina, I.V. and Ljashenko, B.V. (2009), Tehnologichni osnovy mashynobuduvannja, navch. posibnyk in 2 part, Part 1, HDUHT, Harkiv, 202 p.

3. Lovygin, A.A. and Tverdovskii, L.V. (2012), Sovremennyi stanok s ChPU i CAD/CAM-sistema, DMK Press, M., $280 \mathrm{p}$.

4. Lytvynenko, O.A., Bojko, Ju.I. and Janovs'kyj, V.A. (2020), «CAD/CAM tehnologii' proektuvannja ta vygotovlennja detalej na verstatah z ChPK», Tehnichna inzhenerija, No. 1 (85), pp. 15-22.

5. Tyukina, N.V. (2014), «Osobennosti rastachivaniya glubokikh otverstii», Izvestiya TulGU. Tekhnicheskie nauki, Issue 11, Part 1, pp. 189-103.

6. Roukema, J.C. and Altintas, Y. (2007), «Generalized modeling of drilling vibrations: Part II: Chatter stability in frequency domain», Intenational Jornal of Machine Tools \& Manufacture, No. 47, pp. 1474-1485.

7. Siemens NX, [Online], available at: https://www.plm.automation.siemens.com/global/ru/products/nx/

8. Khoroshailo, V.V. (2016), «Povyshenie effektivnosti rastachivaniya otverstii na tokarnykh stankakh putem sozdaniya vibroustoichivoi instrumental'noi sistemy», Abstract of Ph.D. dissertarion, 05.03.01, Donbasskaya gosudarstvennaya mashinostroitel'naya akademiya, Kramatorsk.

9. Zholobov, O.O., Kyrylovych, V.A., Mel'nychuk, P.P. and Janovs'kyj, V.A. (2010), Tehnologija avtomatyzovanogo vyrobnyctva, pidruchnyk, ZhDTU, Zhytomyr, $1014 \mathrm{p}$.

10. Michelle Boucher, Strategiya osnovnykh postavshchikov CAD- i CAE-sistem v 2014 godu i dal'she, [Online], available at: http://www.cadcamcae.lv/N89/22-30.pdf

Бойко Юрій Іванович - кандидат технічних наук, доцент Національного університету харчових технологій.

Наукові інтереси:

- технологія конструкційних матеріалів і машинобудування;

- комп'ютерні технології проєктування.

http://orcid.org/0000-0002-9872-7446.

E-mail: BoykoYI@ukr.net.

Литвиненко Олександр Анатолійович - доктор технічних наук, професор Національного університету харчових технологій.

Наукові інтереси:

- надійність та довговічність обладнання;

- зношування конструкційних матеріалів;

- сучасні конструкційні матеріали.

http://orcid.org/0000-0001-99875-2265.

E-mail: litvinen@nuft.edu.ua.

Яновський Валерій Анатолійович - доцент Державного університету «Житомирська політехніка».

Наукові інтереси:

_ п проєктування технологічного оснащення;

- $\quad$ комп’ютерні технології проєктування.

http://orcid.org//0000-0002-1702-4282.

E-mail: gogolyan2010@gmail.com. 